\title{
GLL
}

$00=0$ Geomatics, Landmanagement and Landscape No. $3 \cdot 2021,83-91$

\section{PROBLEM OF SOIL SCIENCE BASED CLASSIFICATION OF LAND IN THE CONTEXT OF UPDATING LAND AND BUILDING RECORDS}

\author{
Szczepan Budkowski
}

\begin{abstract}
Summary
Pursuant to the Geodetic and Cartographic Law, the soil science based classification of land should be understood as the division of soils into valuation classes due to their productive quality, determined on the basis of soil genetic features. Pursuant to the above-mentioned Act, the task of the starosta (district administrator) is to maintain both the soil science classification of land, and the land and building records (cadastral records). The data that is the subject of the decision issued by the authority in the field of soil science classification of land constitute elements of the essential information set within land and building records, in accordance with Article 23 section 3 point $1 \mathrm{~g}$ of the Geodetic and Cartographic Law [PGiK].

The aim of this publication was to present the irregularities resulting from the failure to update land and building records, as well as from the lack of uniform administrative procedures in the field of soil science classification of land, which translates into the quality of the works performed. The research method used is the case study. The method was supported by the analysis of legislation in the above-mentioned subject matter.
\end{abstract}

Key words

land and building records $\bullet$ soil science based classification of land $\bullet$ law $\bullet$ classifier $\bullet$ space

\section{Introduction - subject matter of the research}

Soil science based classification of land as the task of the starosta (district administrator) is closely related to the land and building records. The classification was defined by the provisions of the statutory rank contained in the Geodetic and Cartographic Law as the division of soils into valuation classes due to their productive quality, determined on the basis of the genetic characteristics of the soil. Article 20 in section 3 of the aforementioned Act indicates that the soil science based classification of land should be conducted in a uniform manner for the whole country, based on the official table of land classes. Its management was entrusted to the starosta (district administrator) competent according to the location of the given real estate property. It is also the starosta who, in parallel to the soil science based classification of land, is obliged to 
keep a register in the format of land and building records. The issues of soil science based classification of land as an executive regulation are defined by the Regulation by the Council of Ministers on the soil science based classification of land of September 12, 2012 (Journal of Laws 2012.1246).

The beginning of the land classification works dates back to the 1920s, when for the first time, due to the Act of July 15, 1920 on the implementation of the land reform (Journal of Laws 1920 No. 70 item 462), the land subdivision plan also encompassed the implementation of a 'detailed classification of land' [land reform]. Subsequently, the classification works were continued on the basis of the Act on the classification of land for land division purposes of March 26, 1935. Another legal act imposing the obligation to carry out a general soil science based classification of agricultural land, based on the principles of soil science was introduced by the Decree of February 2, 1955 on land and building records. Classification works carried out at that time in many areas still remain the only source of information on the productive quality of soils [Bielska and Kupidura 2010]. This state of affairs may be influenced by the fact that the productive quality of soils is determined on the basis of soil genetic characteristics, and these are relatively constant [Cymermann 2011]. An additional argument to consider is the principle of durability of an administrative decision, which remains binding provided that it had been issued without a legal defect [KPA - Administrative Procedure Code].

The regulations currently in force do not regulate the profession of land classifier, and nor do they precisely specify the method of selecting one for the performance of classification procedure - either ex officio or upon request of an interested party. As a consequence, the lack of strictly defined procedures results in a reduction in the quality of cadastral data, as indicated by the Supreme Audit Institution in their latest report on soil science based classification of land in the Kujawsko-Pomorskie Voivodeship [28/2021/P/20/059/LBY].

\section{Discussion and research}

Classification maps were drafted in Poland in the 1960s [Hopfer and Urban 1975]. The classification maps developed in accordance with the regulations were typically prepared at the scale of 1:5000, and sometimes even at the scale of 1:25000 [Strzemski et al. 1964]. Therefore, such studies were burdened with certain errors related to the accuracy and precision of determining the boundaries of classification contours. In addition, all maps created in the process of establishing the records, including classification maps from that period, were developed in the analogue format. In order to analyse the situation in more detail in terms of the quality of cadastral data, with particular emphasis on the aspect of land classification, a study was carried out in the area of the village of Jedlina located in the Bierun-Lędziny district in the Śląskie Voivodeship (Silesia region). The research was conducted in the aforementioned area using:

a) classification contours obtained from the land and building records' database,

b) soil and agricultural maps at a scale of 1:5000, 
c) classification maps in the form of a raster at a scale of 1:5000,

d) data on agricultural land improvement,

e) an orthophotomap.

For the purposes of the research, a database was established for the precincts containing a layer of classification contours from land and building records' databases and a layer of agricultural suitability complexes based on soil and agricultural maps at a scale of 1:5000. Thematic layers with descriptive data were also used, such as:

a) classification contours: type of land use and soil valuation class,

b) agricultural suitability complexes: agricultural suitability complex, soil type, particle size distribution of the soil profile.

The database thus constructed facilitated conducting simple spatial analyses [Budkowski and Litwin 2019], consisting in the juxtaposition and comparison of the accumulated thematic layers. With regard to analogue maps, it further made it possible to compare the boundaries of classification contours. In addition, topicality was also verified by confronting the situation with the current, up-to-date orthophotomap.

The research carried out in the above-mentioned scope, combined with the analysis of the literature on the subject led to the conclusion that classification maps constitute extremely valuable, specific sources of data on soil conditions.

Classification maps developed on the basis of the Decree on the land and buildings' records [the Decree] exist in the analogue format, which, however, is associated with certain problems. As follows from the conducted research and the information obtained from the geodetic documentation centre, for the most part the classification has not been updated, and the existing vector data was obtained from maps at a scale of 1:5000, which means that the thickness of the line on the analogue map may significantly affect the boundaries of the classification contours. Only certain, limited areas were updated - this was done in the case of classification procedures carried out at the request of an interested party - and therefore it can be assumed that generally, the available classification records are not up to date. An exception to this rule may be the changes resulting from the accomplished land improvement and land reclamation tasks, prompted by the conversion of tax status for these lands to agricultural tax.

Information on the location, boundaries, area (surface), types of land use, and land valuation classes are disclosed in the land and building records (Article 20, section 1, point 1 of the Geodetic and Cartographic Law [PGiK]). Pursuant to Article 59 section 6 of the Regulation on land and building records, the records of land located within the precincts include, inter alia, data on land use and soil valuation classes. In turn, the records data for the registration plot includes, inter alia, information specifying the area of land contours and valuation classes within the boundaries of the cadastral plot, pursuant to Article 60 section 1 point 4 of the Regulation on land and building records. The records data for the land use and soil valuation classes include: numerical descriptions of the contours of these land plots and soil valuation classes as well as the designation of land use and soil valuation classes within the individual contours and 
the numbers of these contours. The course of the classification contours is assumed in the records on the basis of the classification map referred to in Article 8 section 2 point 1 of the Regulation on land classification, and it is limited to the contours of agricultural land or forest land (Article 66 sections 1 and 2 of the Regulation on the land and building records). The data contained in the land and building records is for information purposes only, whereas the land and building records themselves reflect the current legal status of a given real estate property. It is declaratory and not constitutive in nature, which means that it does not generate a new legal status of the real estate property, but only confirms the actual state of affairs.

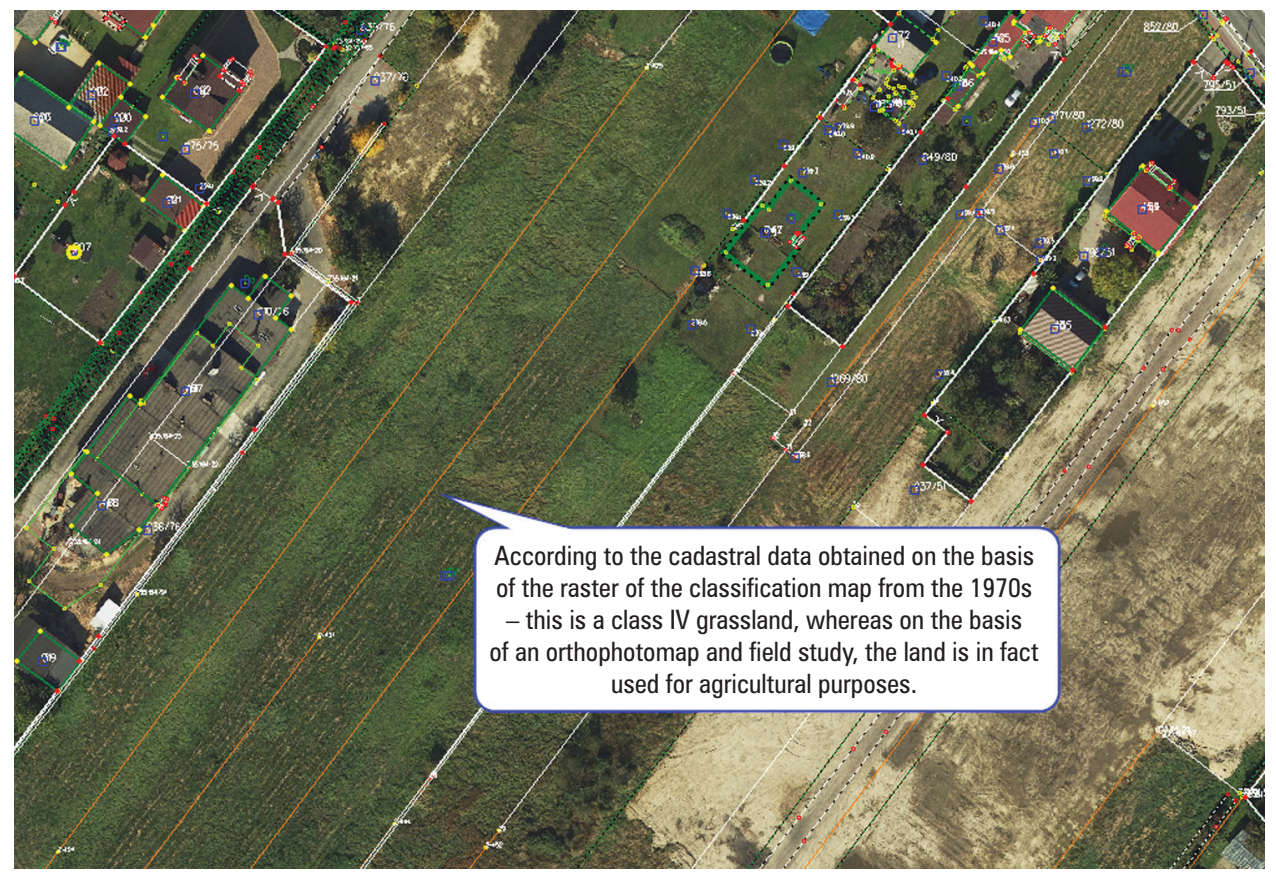

Source: Author's study

Fig. 1. Land use change necessitating the classification procedure

When analysing the given area, the author of the publication encountered out-ofdate cadastral data, which he compared with a recent orthophotomap. The conducted inspection was supported by field visit. Of course, it should be mentioned that the legislator placed the obligation for the notification of the change in land use on the holder of that land, whereas the starosta (district administrator) performs the procedure of soil science classification of land ex officio in strictly defined cases specified in the Regulation of 2012. However, this does not change the fact that the cadastral data is not up-to-date. 
In Figure 1, you can observe the out-of-date content of the cadastral map in terms of the indicated use - featuring erroneously as class IV grassland. During a field visit, it was established that the land is in fact currently used for agriculture. The change of land use implies in this case the necessity to carry out a classification procedure in order to give the land plot its proper designation, and then update the cadastral records. The Geodetic and Cartographic Law indicates that the entities referred to in Article 20 section 2 - i.e. real estate owners, and in the case of local government units other entities apart from owners in whose possession or management the given real estate property remains, within the meaning of the provisions regulating the management of real estate owned by the State Treasury - should notify the competent starosta (district administrator) of changes in the data included in the land and building records, within 30 days from the date of these changes occurring. As shown in selected examples, despite the obligation imposed by the provisions of Article 22 section 2 of the Geodetic and Cartographic Law, the updates often fail to be performed.

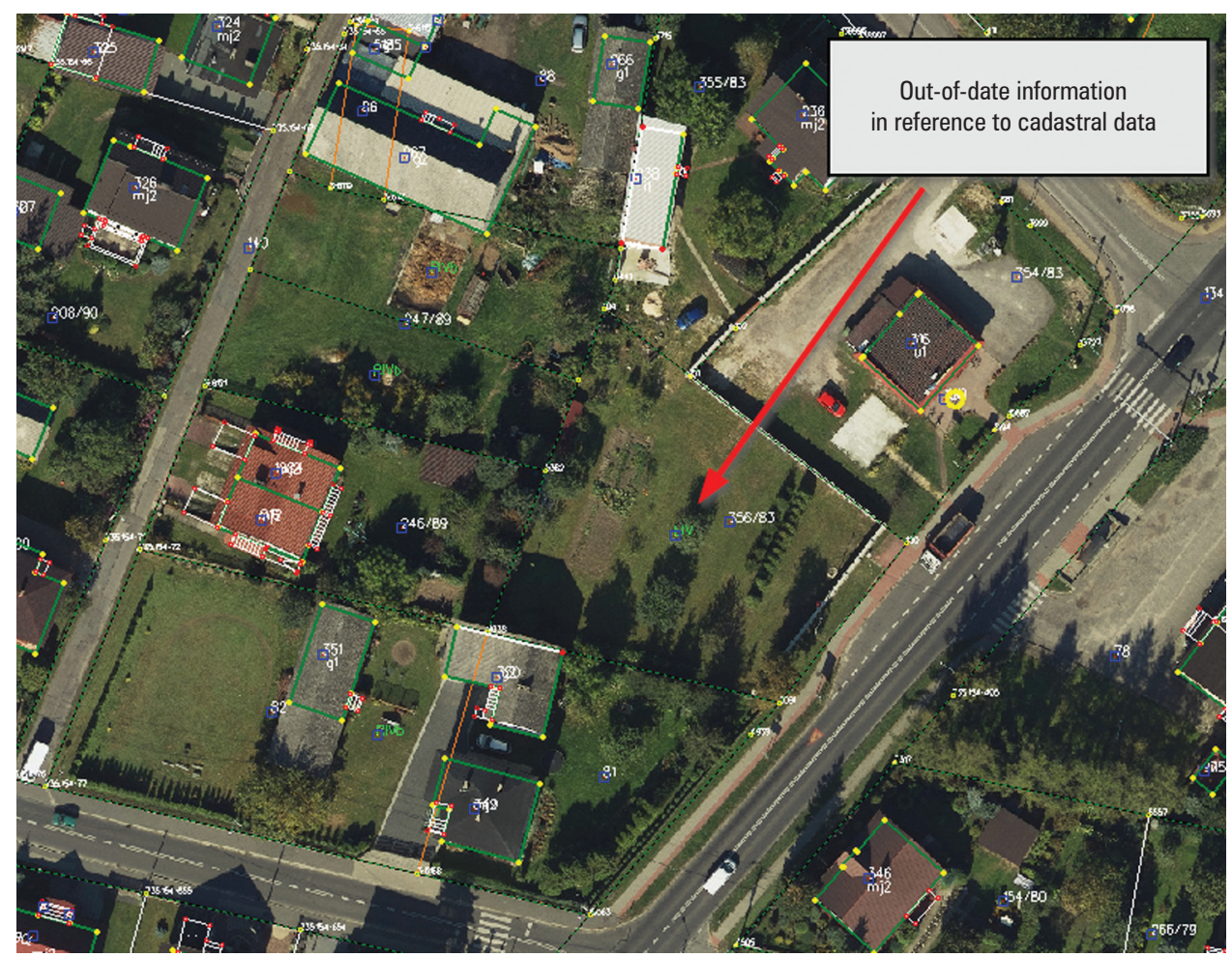

Source: Author's study

Fig. 2. Out-of-date cadastral data for plot no. 356/83 in Jedlina next to Gościnna street 


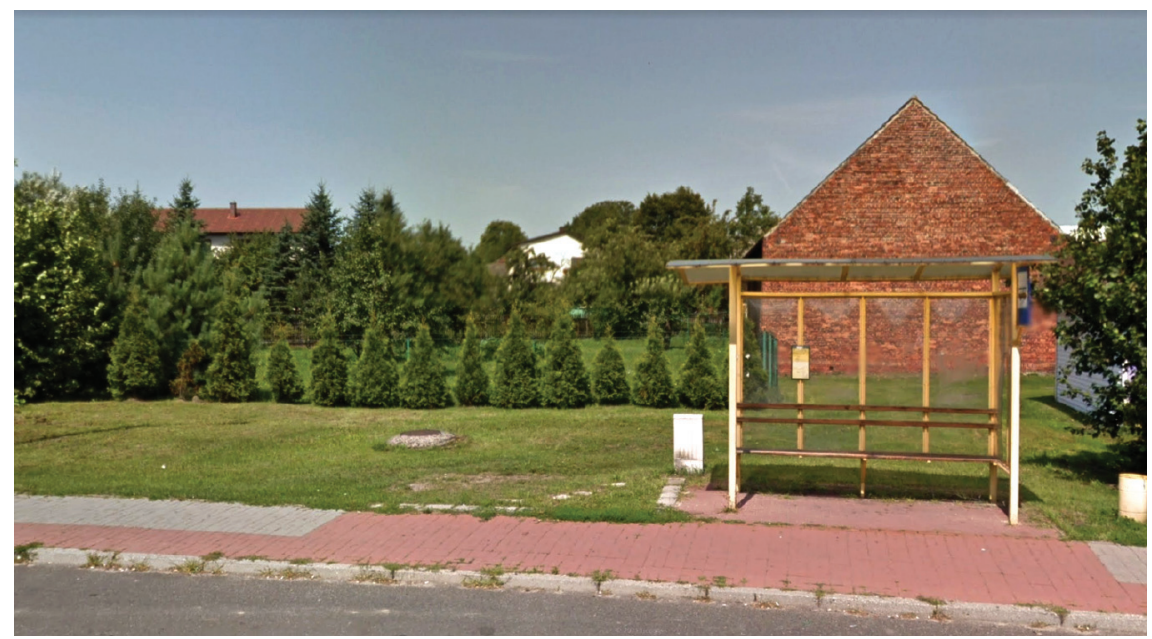

Photo: Sz. Budkowski

Fig. 3. Field visit to plot no. 356/83 in Jedlina, next to Gościnna street

Another case of the missing up-to-date cadastral data concerns plot no. 356/83 located in Jedlina at Gościnna street (Fig. 2). During the field visit, no presence of grassland ( $€$ IV) was found; instead, the area was covered with several year-old trees, and shrubs present in the interior of the plot (Fig. 3). Another case of the lack of up-todate registration data concerns plots 480/5 and 478/5 (Fig. 4), where a similar change in land use can be observed, which has not been introduced in the cadastral map.

The failure to update the cadastral data is not the only problem. Due to the fact that the profession of a classifier is not regulated by an act of statutory rank, and the executive regulations do not define the exact requirements for classifiers, district administrators establish their own, internal requirements applicable in the area of the given district, in the form of ordinances. Some districts currently keep lists of classifiers - a tool that was provided for by former regulations that are no longer applicable today. The fact that lists are kept by some districts, and not by others, as well as the fact that the applicants may also influence the selection of the classifier in some districts may lead to violation of competition rules. Situations in which the selection of a classifier by the applicant is the only criterion may be very dangerous from the legal point of view, creating conditions for violating the impartiality and independence of classifiers, because it is the applicants themselves that contract the soil experts, without the knowledge of the districts. This fact is pointed out by the Supreme Audit Institution [reg. No. 28/2021/P/20/059/LBY], which indicates that the classifiers, when issuing opinions on the soil science classification of land, were placed in a situation of double loyalty, on the one hand to the public interest, and on the other hand, the private. Such a conflict of interest situation is widely regarded as one of the mechanisms leading to corruption.' As the Supreme Audit Institution also indicates, 'in $71 \%$ of the monitored 
cases (10 out of 14), the soil valuation class was underestimated. This proves that the district administrators fail to properly perform their role of the guardians of the priceless natural resource which is agricultural and forest land.

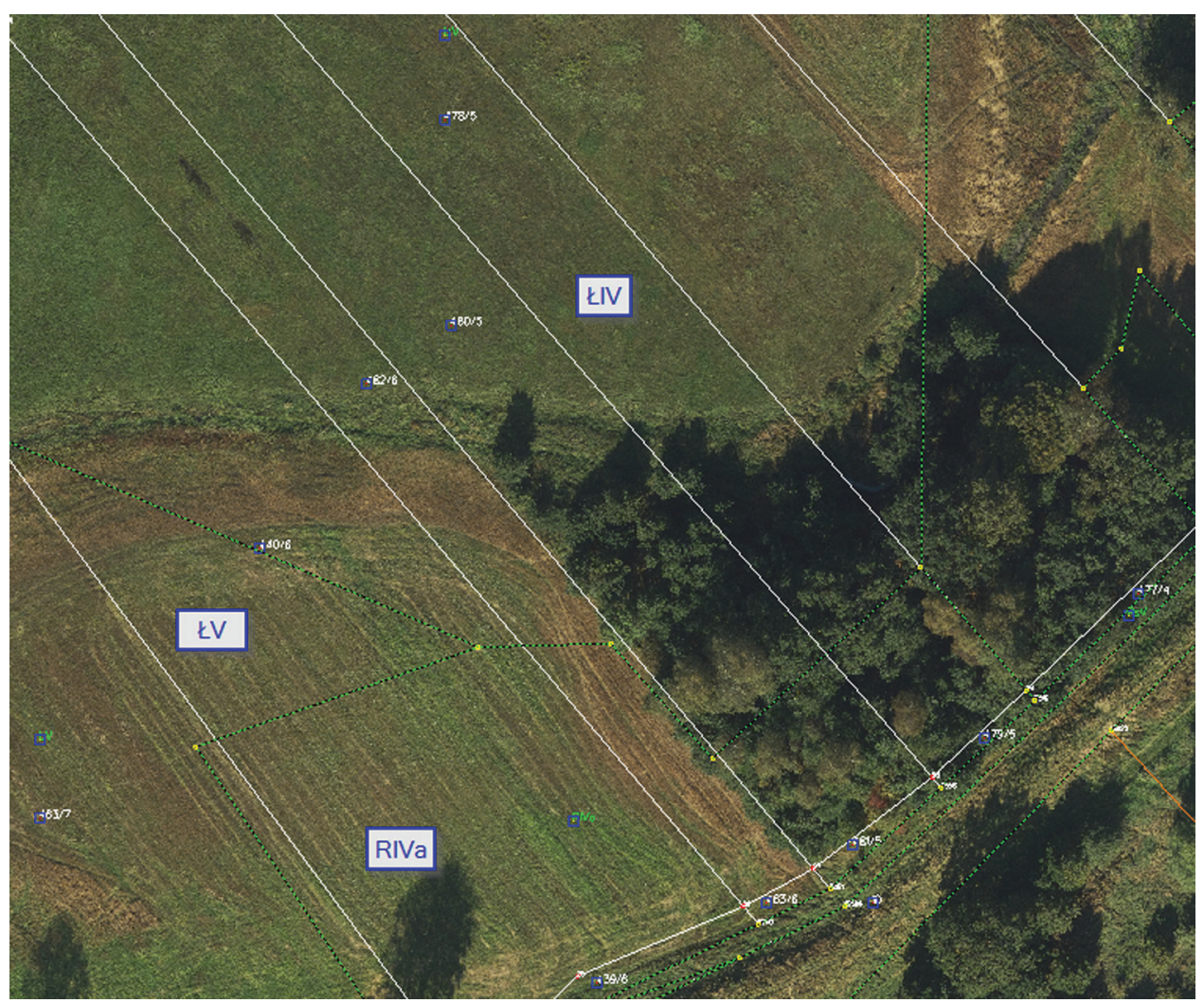

Source: Author's study

Fig. 4. Out-of-date cadastral data - Jedlina, plot no. 480/5 next to Wolska street

\section{Summary and conclusions}

Referring to the issues of soil science in the classification of land, it should be stated that the survey for soil science based classification of land constitutes a record that is separate from the survey of land and buildings. Thus, there is no reason to equate changes in the soil science classification of land with administrative procedures aimed at introducing changes in the land and building records. Changes in the field of cadastral records are introduced in compliance with the administrative rules set out in the Code of Administrative Procedure [KPA], whereas the classification procedure is carried out in accordance with the Ordinance on soil science classification, and it ends with the issuance of an administrative decision. In the land classification procedure, it is 
only possible to establish soil types and classes as well as the contours thereof in terms of agricultural and forest land. However, it is not possible to change the boundaries of types of land use as part of this procedure. Such changes are made in accordance with the principles set out in the Regulation on land records.

Based on the conducted research, it should be stated that the classification maps have not been updated for many years. Their content changed, inter alia, as a result of the conducted land improvement works, changes in land use, and land reclamation projects. In the event of changes in use, the problem can be partially solved by selecting the pertinent areas based on the current orthophotomap. The selected areas can potentially be measured and, if necessary, also subjected to classification procedure. The lack of updates is also important in terms of the accuracy of determining the classification contours, which were determined with an accuracy of 10 meters on the basis of the Instruction G-5: Land and buildings records [the Instruction]. A large portion of analogue classification maps was subjected to vectorisation, and these still remain the only source of classification data. Due to the defined graphical accuracy (1 millimetre on the map, i.e. 5 meters in the field at a scale of 1:5000), the actual course of the classification boundaries may differ.

Referring to the soil science issues of land classification, it should be stated that to introduce the regulation of the classifier profession as well as the pertinent administrative procedures should become a priority for the authorities in the near future. In the opinion of the author of this publication, it is necessary to undertake appropriate legislative work, which, in his opinion, should be included in the Geodetic and Cartographic Law $[\mathrm{PGiK}]$ as an inter-ministerial act with a delegation to the regulation included in its content, as is the case with professional qualifications of geodetic surveyors.

\section{References}

Bielska A., Kupidura A. 2010. Influence of soil conditions on landscape shaping in rural areas. Contemporary problems of management and environmental protection. UWM Olsztyn. Faculty of Environmental Management and Agriculture, Monograph 3A, Natural and Cultural Transformation of Landscape, Chap. 6, 67-82.

Budkowski S., Litwin U. 2019. Synergia w przestrzeni - modelowe ujęcie katastru nieruchomości. Acta Sci. Pol., ser. Formatio Circumiectus, 18(1), 127-135.

Cymermann R. 2011. Podstawy rolnictwa i wycena nieruchomości rolnych. Educaterra, Olsztyn.

Dekret z dnia 2 lutego 1955 r. o ewidencji gruntów i budynków (Dz.U. 1955 nr 6 poz. 32).

Hopfer A., Urban M. 1975. Geodezyjne urządzenia terenów rolnych. PWN, Wrocław.

Informacja o wynikach kontroli. Najwyższa Izba Kontroli. 2021. Wykonanie gleboznawczej klasyfikacji gruntów na terenie województwa kujawsko-pomorskiego, delegatura w Bydgoszczy. LBY.430.001.2021. Nr ewid.28/2021/P/20/059/LBY.

Instrukcja G-5. Ewidencja gruntów i budynków. Zarządzenie nr 16 Głównego Geodety Kraju z 3 listopada 2003 roku.

Kodeks postępowania administracyjnego z dnia 14 czerwca 1960 r. (Dz.U. 1960 nr 30 poz. 168) [KPA].

Rozporządzenie Rady Ministrów z dnia 4 czerwca 1956 roku w sprawie klasyfikacji gruntów wraz z załączoną tabelą klas gruntów (Dz.U. 1956 nr 19 poz. 97) [klas 1956]. 
Rozporządzenie Rady Ministrów z dnia 12 września 2012 r. w sprawie gleboznawczej klasyfikacji gruntów (Dz.U. 2012 poz. 1246) [klas 2012].

Rozporządzenie Ministra Rozwoju Regionalnego i Budownictwa z dnia 29 marca 2001 roku w sprawie ewidencji gruntów i budynków (Dz.U. 2001 nr 38 poz. 454 ze zm.) [egib].

Siuta J., Witek T. 1973. Przydatność rolnicza gleb Polski. PWRiL, Warszawa.

Strzemski M., Bartoszewski Z., Czarnowski F., Dombek E., Siuta J., Truszkowska R., Witek T. 1964. Instrukcja w sprawie wykonywania map glebowo-rolniczych w skali 1: 5000 i 1: 25000 oraz map glebowo-przyrodniczych w skali 1: 25 000. Załącznik do Zarządzenia nr $115 \mathrm{Mi}$ nistra Rolnictwa z dnia 28 lipca 1964 r. w sprawie organizacji prac gleboznawczo- i rolniczo-kartograficznych. (Dz. Urz. Min. Rol. nr 19, poz. 121).

Ustawa z dnia 15 lipca 1920 r. o wykonaniu reformy rolnej (Dz. U. 1920 nr 70 poz. 462) [reforma rolna].

Ustawa z dnia 17 maja 1989 roku Prawo geodezyjne i kartograficzne (Dz.U. 1989 nr 30 poz. 163 ze zm.) [pgik].

Zarządzenie nr 127 Ministra Rolnictwa z dnia 14 czerwca 1956 roku w sprawie zasad i metod technicznego wykonania klasyfikacji gruntów oraz wymaganych kwalifikacji dla osób przeprowadzających tę klasyfikację.

Dr inż. Szczepan Budkowski

University of Agriculture in Krakow

Department of Geodesy

ul. Balicka 253a, 30-149 Kraków

Correspondence address:

al. Mickiewicza 21, 30-120 Kraków

e-mail: Szczepan.budkowski@urk.edu.pl

ORCID: 0000-0002-1806-1173 